\title{
Infectivity and effectiveness of different species of arbuscular mycorrhizal fungi in micropropagated plants of Mr S 2/5 plum rootstock
}

\author{
P Fortuna 1, S Citernesi 2, S Morini 1, M Giovannetti 3, F Loreti 1 \\ 1 Universita' di Pisa, Dipertimento di Coltivazione e Difesa delle Specie Legnose, Sezione di Coltivazioni Arboree, Pisa; \\ 2 Scuola Superiore di Studi Universitari e Perfezionamento "S Anna", Pisa; \\ 3 Universita di Pisa, Istituto di Microbiologia Agraria e Centro di Studio per la Microbiologia del Suolo, Pisa, Italy
}

(COST Meeting, 21-23 May 1992, Dijon, France)

\begin{abstract}
Summary - Micropropagated plum plants (Prunus cerasifera Ehrh clone MrS 2/5) were inoculated with 4 different species of arbuscular mycorrhizal fungi (Glomus mosseae, G caledonium, G coronatum and Glomus strain A6) after transfer from an in vitro to an in vivo system. The most and the least infective fungi, $G$ mosseae and $G$ coronatum respectively, were tested for their growth-promoting abilities with respect to the micropropagated plum plants. Both fungi improved plant growth in comparison with uninoculated plants. $G$ coronatum showed a prolonged lag phase during the early stage of mycorrhizal infection and affected growth less than $G$ mosseae at the first harvest (4 wk). At the second harvest (14 wk), when mycorrhizal infection by both fungi was high, $G$ coronatum was as effective as $G$ mosseae in promoting plant growth of $P$ cerasifera. The importance of a rapid mycorrhizal infection during the acclimatization phase of micropropagated plants is discussed in this paper.
\end{abstract}

infectivity / effectiveness / AM fungi / micropropagated plant / Prunus cerasifera

Résumé - Infectivité et efficacité de différentes espèces de champignons mycorhiziens arbusculaires chez les vitroplants de porte-greffe de prunier MrS 2/5. Des vitroplants de prunier (Prunus cerasifera Ehrh clone Mr.S.2/ 5) ont été inoculés post-vitro avec 4 champignons endomycorhizogènes : Glomus mosseae, G caledonium, $G$ coronatum et Glomus souche $A 6$, dans le but d'évaluer les paramètres d'infection. Les champignons le plus infectieux (G mosseae) et le moins infectieux (G coronatum) ont été respectivement sélectionnés et leur capacité d'influencer la croissance de vitroplants de prunier a été évaluée. Ces 2 champignons ont un effet positif sur la croissance des plants inoculés. G coronatum montrait un temps de latence prolongé pendant les premiers stades d'infection mycorhizienne; on ne constate pas au premier prélèvement (4 semaines) une augmentation de croissance végétale comparable à celle obtenue avec $\mathrm{G}$ mosseae. Au deuxième prélèvement (14 semaines), quand les 2 champignons présentaient un taux élevé d'infection mycorhizienne, $\mathrm{G}$ coronatum se révélait aussi efficace que $\mathrm{G}$ mosseae pour stimuler la croissance de $\mathrm{P}$ cerasifera. Ce travail permet de discuter de limportance d'une infection mycorhizienne rapide au cours de la phase d'acclimatation de vitroplants.

infectivité / efficacité / champignon mycorhizien arbusculaire / plant micropropagé / Prunus cerasifera 


\section{INTRODUCTION}

In arbuscular mycorrhizal (AM) symbiosis, the ability of a fungal species to infect a host plant both rapidly and extensively may play an important role in determining the success of the relationship. The main parameters which can be utilized to measure this type of host affinity are fungal infectivity, plant mycotrophy and the growth promoting ability of AM fungi.

The effectiveness of combining different $A M$ fungi and host plants has been largely studied in plants (Plenchette et al, 1982; Geddeda et al, 1984; Doud Miller et al, 1985; Schubert and Cammarata, 1986; Giovannetti and Lioi, 1987, including micropropagated plants (Morandi et al, 1979; Pons et al, 1983; Gianinazzi et al, 1986; Ravolanirina et al, 1989). Nevertheless, little is known about the early stages of AM infection in these plants, though early root colonization has been demonstrated to be very important during the delicate acclimatization phase (Ravolanirina et al, 1989; Gianinazzi et al, 1990).

In the present study we tested the fungal infectivity of 4 species of AM fungi, Glomus caledonium (Nicol et Gerd) Trappe et Gerd, G coronatum Giovannetti, $G$ mosseae (Nicol et Gerd) Gerd et Trappe, and a strain of Glomus, denominated $A 6$, on micropropagated plants of a rootstock clone (MrS 2/5) selected from Prunus cerasifera Ehrh seedlings. The most and the least infective fungi were selected to investigate whether and how a delay in mycorrhizal infection would affect their growth-promoting abilities.

\section{MATERIALS AND METHODS}

\section{Experiment 1}

Shoots of the MrS 2/5 plum clone were grown for 3 wk in vitro in an appropriate rooting medium (Morini et al, 1990). Microplants were then transplanted into pots filled with a substratum composed of 1 part sterile sand and 1 part crude AM inoculum (v:v). Crude AM inoculum consisted of infested soil which contained (as infective propagules) spores, external mycelium and infected root fragments obtained from alfalfa potcultures inoculated with $G$ caledonium, $G$ coronatum, $G$ mosseae or Glomus A6. Plants were grown in a growth chamber with a 14-h day according to the procedure generally adopted for acclimatization (Morini and Barbieri, 1986). Two wk after inoculation, plantlets were harvested and roots stained with trypan blue in lactic acid (Phillips and Hayman, 1970). Infected root pieces, selected under the dissecting microscope, were mounted on slides and the morphology and frequency of appressoria were observed using a Reichert-Jung Polyvar microscope.

\section{Experiment 2}

Micropropagated plantlets of the MrS $2 / 5$ plum clone were transplanted into $0.1-1$ pots containing a substratum consisting of 1 part crude AM inoculum, 1 part sterile peat and 1 part sterile perlite (v:v:v). The crude inoculum was obtained from sunflower pot cultures inoculated with $G$ coronatum and $G$ mosseae. In uninoculated control plants, the AM inoculum was replaced by the same sterilized soil utilized for pot culture production (a sandy soil, pH 7.3, 16.4 ppm available $P)$. Plants were maintained in a greenhouse, from June to September, adopting a suitable procedure for acclimatization (Morini and Barbieri, 1986). One month after transplanting, the content of each pot was transferred into a 1-I pot containing the same soil used in the control treatment. Plants were fertilized twice a week with $50 \mathrm{ml} /$ pot of half-strenght Hoagland solution without phosphorus. The number of surviving plants was recorded after $30 \mathrm{~d}$. Two harvests were performed, 4 and 14 wk after transplanting. At each harvest, fresh shoot and root mass, and height of 10 replicate plants per treatment were measured. AM infection was assessed after staining the roots with trypan blue (Phillips and Hayman, 1970; Giovannetti and Mosse, 1980). Dry shoot mass, measured at the second harvest, was obtained after drying the shoots for $48 \mathrm{~h}$ at $90^{\circ} \mathrm{C}$. All data from the 2 experiments were statistically analyzed using 1-way analysis of variance and averages were separated by Tuckey's test.

\section{RESULTS}

\section{Experiment 1}

Two wk after inoculation, $G$ caledonium, $G$ mosseae and Glomus A6 had already infected plum roots, and many appressoria were clearly visible on the root surface. In contrast $G$ coronatum had developed a much lower number of appressoria than that formed by the other AM fungi (table I).

Three main shapes of appressoria were identified: lenticular, amoeboid and mamillary. The mamillary shape was characteristically formed by Glomus A6. Significant differences in the length of appressoria, formed by different endophytes, were found in the lenticular and amoeboid shape. The number of appressoria/mm root formed by $G$ mosseae was significantly higher than those of the other fungal species (table I). 
Table I. Shape, number and occurrence of appressoria formed by Glomus mosseae, G caledonium, Glomus A6 or $G$ coronatum on roots of plum rootstock 2 wk after inoculation.

\begin{tabular}{|c|c|c|c|c|}
\hline Appressoria & $\begin{array}{l}\text { Glomus } \\
\text { mosseae }\end{array}$ & $\begin{array}{c}\text { Glomus } \\
\text { caledonicum }\end{array}$ & $\begin{array}{c}\text { Glomus } \\
\quad A 6\end{array}$ & $\begin{array}{c}\text { Glomus } \\
\text { coronatum }\end{array}$ \\
\hline Number (per mm root) & $9.72^{a^{\star}}$ & $6.60^{\mathrm{b}}$ & $6.76^{\mathrm{b}}$ & $0.25^{c}$ \\
\hline \multicolumn{5}{|l|}{ Lenticular } \\
\hline Occurrence (\%) & 56 & 55 & 53 & - \\
\hline Length $(\mu \mathrm{m})$ & $28.75^{a}$ & $21.27^{b}$ & $27.18^{a}$ & - \\
\hline Width $(\mu \mathrm{m})$ & $11.50^{\mathrm{a}}$ & $11.69^{a}$ & $11.09^{a}$ & - \\
\hline \multicolumn{5}{|l|}{ Amoeboid } \\
\hline Occurrence (\%) & 30 & 37 & - & - \\
\hline Length $(\mu \mathrm{m})$ & $30.53^{a}$ & $22.49 \mathrm{~b}$ & - & - \\
\hline Width $(\mu \mathrm{m})$ & $20.49^{a}$ & $17.02^{\mathrm{a}}$ & - & - \\
\hline \multicolumn{5}{|l|}{ Mamillary } \\
\hline Occurrence (\%) & - & - & 11 & - \\
\hline Length $(\mu \mathrm{m})$ & _- & - & 62.80 & - \\
\hline Width $(\mu \mathrm{m})$ & - & - & 15.33 & - \\
\hline \multicolumn{5}{|l|}{ Others } \\
\hline Occurrence $(\%)$ & 14 & 8 & 36 & - \\
\hline
\end{tabular}

*Values in rows followed by the same letter do not differ significantly at $P=0.05$

\section{Experiment 2}

The most and the least infective AM fungal species in Experiment 1, G mosseae and $G$ coronatum respectively, were tested for their ability to improve plant growth after transplanting microplants from the in vitro to an in vivo culture. After 4 wk growth the number of surviving plants was $\approx$ $100 \%$ in all treatments. The fresh mass of the plant roots inoculated with $G$ mosseae was significantly higher than that of the uninoculated controls and of plant roots uninoculated with $G$ coronatum (table II). The fresh mass and height of shoots did not differ, regardless of the treatment (tables II, III). Percentage of mycorrhizal infection was 8 and $38.5 \%$ of root length in $G$ coronatum and in $G$ mosseae infected plants respectively (table III). At the second harvest (14 wk growth), control plants showed a significantly lower fresh and dry mass whereas mycorrhizal plants showed comparable growth increases (table II). It is important to note that the growth of control plants was blocked after transplanting, and shoot apices failed to resume activity during the entire experiment. At the final harvest, the percentage of mycorrhizal infection in plants ino- culated with $G$ coronatum was similar to that obtained in plants inoculated with $G$ mosseae (table III).

Table II. Growth of plum rootstock 4 and 14 wk after inoculation with Glomus mosseae or $G$ coronatum as compared to uninoculated control plants.

\begin{tabular}{|c|c|c|c|}
\hline \multirow[t]{2}{*}{ Treatment } & \multicolumn{2}{|c|}{ Fresh mass $(g)$} & \multirow{2}{*}{$\frac{\text { Dry mass }(g)}{\text { Shoot }}$} \\
\hline & Shoot & Root & \\
\hline \multicolumn{4}{|l|}{$4 \mathrm{wk}$} \\
\hline$G$ mosseae & $0.65^{a^{*}}$ & $0.45^{\mathrm{a}}$ & - \\
\hline G coronatum & $0.57^{\mathrm{a}}$ & $0.34^{b}$ & - \\
\hline Control & $0.55^{a}$ & $0.34^{b}$ & - \\
\hline \multicolumn{4}{|l|}{$14 w k$} \\
\hline G mosseae & $3.97^{a^{\star}}$ & $3.75^{\mathrm{a}}$ & $1.20^{\mathrm{a}}$ \\
\hline G coronatum & $3.76^{a}$ & $3.58^{a}$ & $1.11 \mathrm{a}$ \\
\hline Control & $0.70^{\mathrm{b}}$ & $1.45^{b}$ & $0.27^{b}$ \\
\hline
\end{tabular}

* For each growth period values in columns followed by the same letter do not differ significantly at $P=0.05$. 
Table III. Height and percentage of infected root length in plum rootstock 4 and 14 wk after inoculation with Glomus mosseae or $G$ coronatum as compared to uninoculated control plants.

\begin{tabular}{|c|c|c|c|c|}
\hline \multirow[t]{2}{*}{ Treatment } & \multicolumn{2}{|c|}{ Height $(\mathrm{cm})$} & \multicolumn{2}{|c|}{$\%$ infection } \\
\hline & $\begin{array}{l}\text { After } \\
4 w k\end{array}$ & $\begin{array}{l}\text { After } \\
14 \text { wk }\end{array}$ & $\begin{array}{l}\text { After } \\
4 w k\end{array}$ & $\begin{array}{l}\text { After } \\
14 w k\end{array}$ \\
\hline Glomus mosseae & $5.7^{a^{\star}}$ & $20.6^{a}$ & $38.5^{a}$ & $71.0^{\mathrm{a}}$ \\
\hline Glomus coronatum & $6.5^{a}$ & $21.0^{\mathrm{a}}$ & $8.0^{b}$ & $66.0^{\mathrm{a}}$ \\
\hline Control & $5.5^{a}$ & $5.3^{b}$ & $\mathrm{O}^{\mathrm{C}}$ & $0^{b}$ \\
\hline
\end{tabular}

* Values in columns followed by the same letter do not differ significantly at $P=0.05$.

\section{DISCUSSION AND CONCLUSION}

The results of this experiment show that a delay in mycorrhizal infection can negatively affect the growth of the micropropagated plum rootstock clone MrS2/5 during the early acclimatization stages. $G$ coronatum infected roots very slowly, forming a low number of appressoria on the root surface and colonizing only $8 \%$ of the length of the plum roots after $4 \mathrm{wk}$. These data confirm previous results concerning the erratic germinability and the low infectivity of this endophyte (Giovannetti et al, 1991). The prolonged lag phase at the beginning of mycorrhiza establishment led to poor root infection, which failed to give early growth increases. In fact, only 4 wk after transplanting, fresh root mass of plantlets inoculated with the highly infective endophyte $G$ mosseae were significantly higher than those of plants inoculated with $G$ coronatum. However, at the later harvest (14 $w k)$, infection by $G$ coronatum (66\%) was as extensive as that of $G$ mosseae $(71 \%)$ and both fungi were equally effective in promoting plant growth. Growth differences between mycorrhizal and control plants were very large, confirming the importance of mycorrhizal inoculation for micropropagated plants (Ravolanirina et al, 1989; Gianinazzi et al, 1990). The high amount of inoculum used in both experiments overcame problems linked to differences in the infection potential of the fungi and which can occur when low concentrations of inoculum are used (Porter, 1979; Daniels et al, 1981; Lioi and Giovannetti, 1987).

The large differences obtained in fresh and dry mass between mycorrhizal and uninoculated control plants also resulted from differences in the growth behaviour of the plants. In fact, micropropagated plants frequently show blocked apical growth just after transplanting ("transplant shock"), and renewed growth occurs at different periods, depending on nutritional and environmental conditions as, for example, reported for peach plants (Morini and Concetti, 1984). The plum rootstock clone MrS 2/5 showed similar behaviour, but with mycorrhizal inoculation renewed apical growth began in most plants the first month after transplanting, whilst uninoculated controls did not actively grow and apices remained blocked up to the end of the experiment. This is a very interesting result, probably indicating that additional effects other than nutritional ones such as hormone balance modifications are produced by mycorrhizal symbiosis as suggested by Allen et al (1980, 1982). Nevertheless, further studies are necessary to determine the physiological basis of the positive role of the mycorrhizal infection in promoting apical activity of transplanted micropropagated plum plants.

\section{ACKNOWLEDGMENTS}

This research was supported by the National Research Council of Italy, Special Project RAISA, subproject No 2, paper No 543.

\section{REFERENCES}

Allens MF, Moore TS, Christensen JR, Christensen M (1980) Phytohormone changes in Bouteloua gracilis infected by vesicular-arbuscular mycorrhizae. I. Cytokinin increases in the host plant. Can $J$ Bot 58, 371-374

Allens MF, Moore TS, Christensen M (1982) Phytohormone changes in Bouteloua gracilis infected by vesicular-arbuscular mycorrhizae. II. Altered levels of gibberellin-like substances and abscisic acid in the host plant. Can J Bot 60, 468-471

Daniels BA, McCool PM, Menge JA (1981) Comparative inoculum potential of spores of six vesiculararbuscular mycorrhizal fungi. New Phytol 89, 385-391

Doud Miller D, Domoto PA, Walker C (1985) Colonization and efficacy of different endomycorrhizal fungi with apple seedlings and two phosphorus levels. New Phytol 100, 393-402

Geddeda YI, Trappe JM, Stebbins RL (1984) Effect of vesicular-arbuscular mycorrhizae and phosphorus on apple seedlings. J Am Soc Hortic Sci 109, 24-27

Gianinazzi S, Gianinazzi-Pearson V, Trouvelot A (1986) Que peut-on attendre des mycorhizes dans la production des arbres fruitiers ? Fruits 41, 553-556 
Gianinazzi S, Trouvelot A, Gianinazzi-Pearson V (1990) Role and use of mycorrhizas in horticultural crop production. Adv Hort Sci 4, 25-30

Giovannetti M, Mosse B (1980) An evaluation of techniques for measuring vesicular-arbuscular mycorrhizal infection in roots. New Phytol 84, 489-500

Giovannetti M, Avio L, Salutini L (1991) Morphological, cytochemical, and ontogenetic characteristic of a new species of vesicular-arbuscular mycorrhizal fungus. Can J Bot 69, 161-167

Lioi L, Giovannetti M (1987) Variable effectivity of three vesicular-arbuscular mycorrhizal endophytes in Hedysarum coronarium and Medicago sativa. Biol Fertil Soil 4, 193-197

Morandi D, Gianinazzi S, Gianinazzi-Pearson V (1979) Intérêt de l'endomycorhization dans la reprise et la croissance des framboisiers issus de multiplication végétative in vitro. Ann Amelior Plant 29, 23-30

Morini S, Concetti S (1984) In vitro propagation of PS B2 peach rootstock. Acta Hortic 173, 205-210

Morini S, Barbieri C (1986) La propagazione in vitro: fattori che condizionano l'acclimatazione delle piantine. Inform Agrar 2, 67-71

Morini S, Fortuna P, Sciutti R, Muleo R (1990) Effect of different light-dark cycles on growth of fruit tree shoots cultured in vitro. Adv Hortic Sci 4, 163-166
Phillps JM, Hayman DS (1970) Improved procedures for clearing roots and staining parasitic and vesicular-arbuscular mycorrhizal fungi for rapid assessment of infection. Trans Br Mycol Soc 55, 158-161

Plenchette C, Furlan V, Fortin A (1982) Effects on different endomycorrhizal fungi on five host plants grown on calcinated montmorillonite clay. $J A m$ Soc Hortic Sci 107, 535-538

Pons F, Gianinazzi-Pearson V, Gianinazzi S, Navatel JC (1983) Studies of VA mycorrhizae in vitro: mycorrhizal synthesis of axenically propagated wild cherry (Prunus avium L) plants. Plant Soil 71, 217 221

Porter WN (1979) The "most probable number" method for enumerating infective propagules of the vesicular-arbuscular mycorrhizal fungi in soil. Aust J Soil Res 17, 515-519

Ravolanirina F, Blal B, Gianinazzi S, GianinazziPearson V (1989) Mise au point d'une méthode rapide d'endomycorhization de vitroplant. Fruit 44, 165-170

Schubert A, Cammarata S (1986) Effect of inoculation with different endophytes on growth and $P$ nutrition of grapevine plants grown in pots. In: Mycorrhizae: Physiology and Genetics (Gianinazzi-Pearson V, Gianinazzi S, eds) INRA, Paris, 327-331 